\title{
The Corinth Rift Laboratory or an in situ Investigation on Interactions between Fluids and Active Faults
}

by François Henri Cornet

\section{Objectives}

Earthquakes result from the sudden acceleration of a preliminary long-term slow deformation process. The objective of the Corinth Rift Laboratory (CRL) is to investigate in situ this quasistatic deformation process and mechanisms leading to a sudden catastrophic acceleration. Of particular interest is the characterization of the structure of the deforming zones and of the progressive localization of deformation. Special attention is given to the role of fluids but also on the influence of faults on regional fluid flow.

\section{Corinth Rift Laboratory}

The Gulf of Corinth, in western Greece, is one of the most seismically active regions in Europe. It is possibly the fastest continental rift in the world and provides an ideal site for an in situ investigation of the physics of earthquake sources and for developing efficient seismic hazard reduction procedures. It was selected several years ago, after an Intenational Continental Scientific Drilling Program (ICDP) supported workshop (Cornet et al., 1997), as a site for developing an in situ laboratory, the CRL.

The Corinth Rift (Fig. 1), which separates the Peloponnesus from continental Greece, is a $110-\mathrm{km}$-long, $\mathrm{N} 110^{\circ}$ E-oriented graben, bound by systems of very recent steeply dipping normal faults less than 2 Myr old (Armijo et al., 1996; Jolivet et al., 2004; Le Pichon et al., 1995). This structure is the site of continental break-up, with up to $1.5 \mathrm{~cm}$ $\mathrm{yr}^{-1}$ of north-south extension and a few millimeters per year uplift of the southern shore (Avallone at al., 2004; Briole et al., 2000; Pantosti et al., 2004). This rapid opening is associated with a shallowly northdipping seismic zone located at depths ranging from $6 \mathrm{~km}$ to $12 \mathrm{~km}$ (Bernard et al., 2006; Gautier et al., 2006; Rigo et al., 1996). Five events with magnitude larger than 5.8 have been recorded in this region within the last forty years. The rifting is associated with the subduction to the southwest of Peloponnesus but also possibly to the propagation of the North Anatolian Fault.

CRL (www.corinth-rift-lab.org; Comptes Rendus Geosciences, 2004) is located in the vicinity of the city of Aigion, some $40 \mathrm{~km}$ east of Patras. It covers an area about $30 \mathrm{~km} \times 30 \mathrm{~km}$, extending across the gulf between Aigion on the southern shore and Eratini on the northern shore. This area was chosen for several reasons:

- The local strain rate and the microseismicity are highest $\left(1.5 \times 10^{-6}\right.$ per year);

- The faults in this area have not been the site of any earthquake of magnitude larger than 5.5 for more than a century (three centuries for the western part). Further, from GPS data analysis, these faults are considered to be in the final stage of their seismic cycle (a few decades) and in a state of accelerated strain (Bernard et al. 2006);

- These faults were recently loaded by the 1995 , magnitude 6.2, so-called Aigion earthquake, at the north eastern edge of the area (Bernard et al., 1997);

- The gulf is less than $8 \mathrm{~km}$ wide there, allowing on-land access to instrumented sites.

The CRL involves the monitoring of seismic activity with a network of twelve three-component $(2-\mathrm{Hz})$ seismic stations and three broadband stations; the monitoring of surface deformation by continuous GPS, high resolution surface

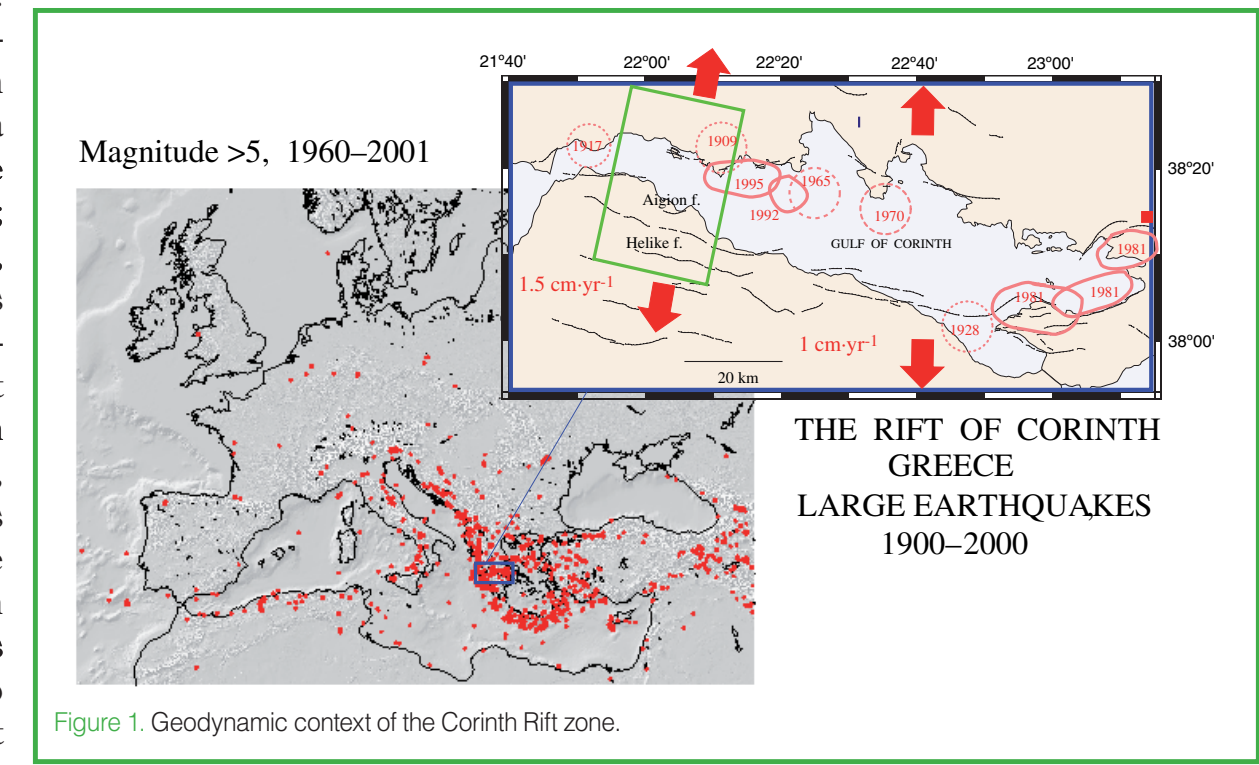


tiltmeters, and downhole strainmeters; and the monitoring of water level or flow rate variations of natural springs and their changes in chemical composition, including rare gas content. In addition, it involves deep boreholes (presently two) for better characterization of the geological structure and for in situ monitoring of fluid-fault interactions.

One of the goals of the CRL is to understand the geometric connections between the outcropping steeply dipping fault planes and the deeper shallowly dipping seismogenic zone. Another goal is to explore the relationship between seismic and non-seismic deformation, with particular attention to the role of circulating fluids, for only about $40 \%$ of observed deformations (last five years) can be accounted for by the cumulated seismic activity.

More than five years of observation are presently available (Fig. 2). Of particular interest is the microseismic crisis (maximum magnitude 3.5) along the Aigion fault, that started about one month after the 1000-m-deep AIG10 borehole (Cornet et al., 2004) modified the hydraulic conditions in the upper part of the fault (October 2004). The destabilization of the fault in its upper portion is evidenced by minute (40-80 Pa) pressure drops (Fig. 3) dynamically triggered by large distant earthquakes (magnitude $\geq 8$ with epicenters located more than $10,000 \mathrm{~km}$ away). The crisis, which lasted about five months, migrated westward and downward and generated more than 2000 events, many of which are multiplets. Preliminary results outline the

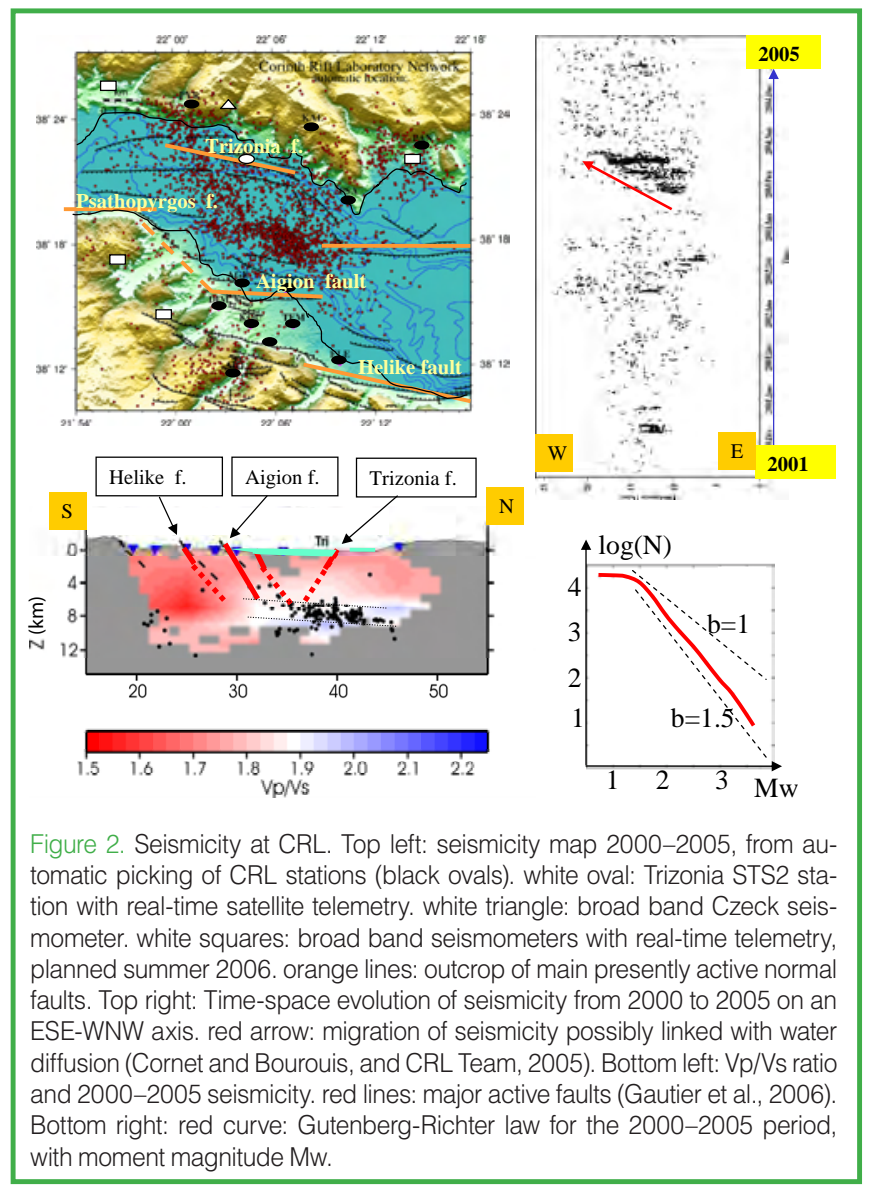

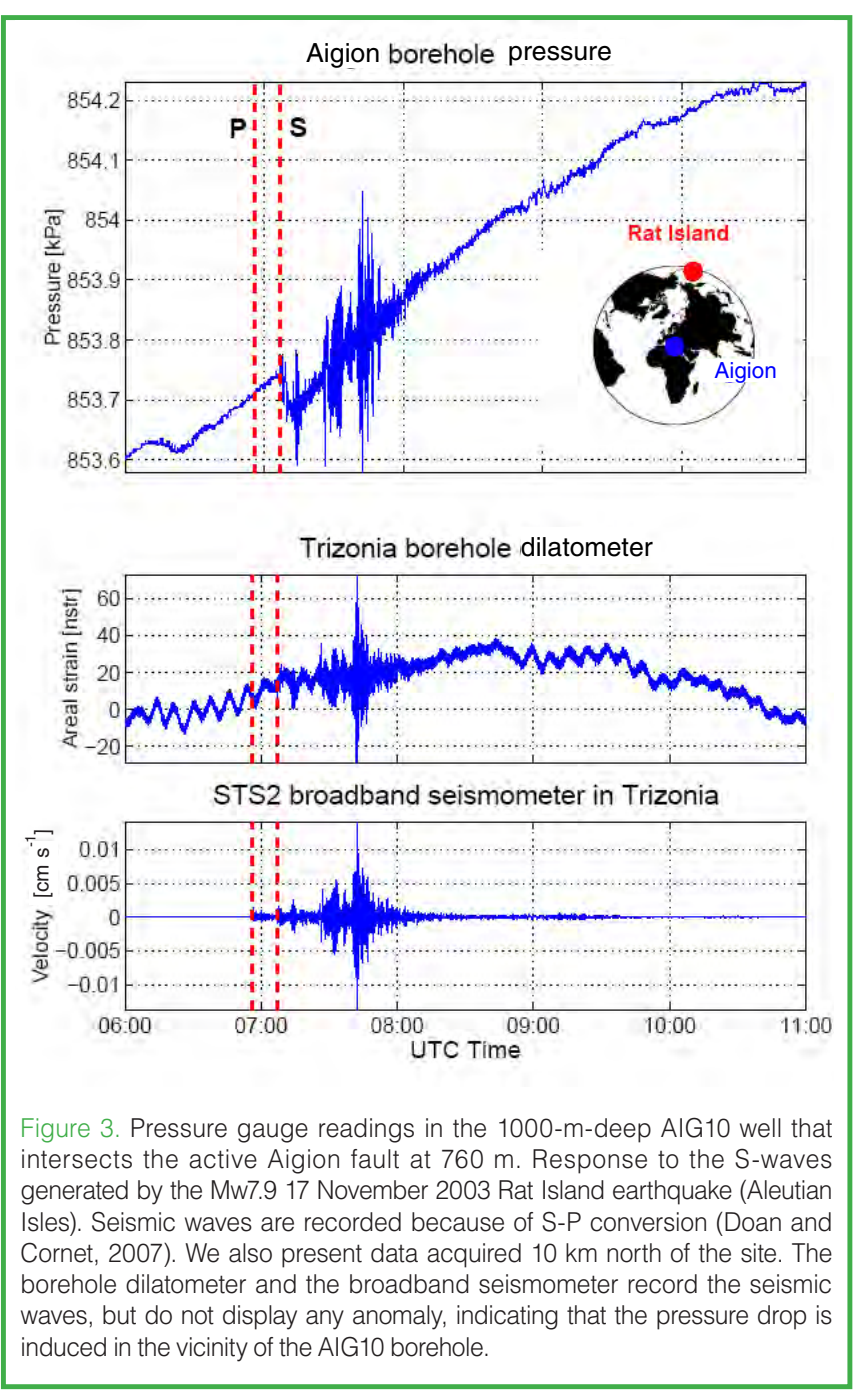

existence of subvertical slip planes, some of which are strike slip (Bourouis et al., 2005; Cornet et al., 2005) as well as low dip fault planes. This is in contrast with the other most significant seismic crisis (2001) observed during the five-year life span of CRL existence that occurred in a zone that was thought to be inactive. The 2001 crisis is much more localized and is thought to have been associated with upward fluid motion (Lyon-Caen et al., 2004).

The 1000-m-deep AIG10 well intersects around $760 \mathrm{~m}$ the $10-\mathrm{km}$-long Aigion normal fault that was reactivated during the 1995 magnitude 6.2 Aigion earthquake. Below the Aigion fault, the AIG10 well entered a karstic limestone with a $0.9 \mathrm{MPa}$ overpressure, while the aquifer just above the fault was found also to be artesian with a $0.45 \mathrm{MPa}$ overpressure. The fault is about $10 \mathrm{~m}$ thick and involves an argileous $60-\mathrm{cm}-$ thick core. Within this clay zone, observed slip direction is consistent with the maximum principal stress component being normal to the main fault plane (Sulem, 2007).

Also significant is the observation of a transient creeping process (Fig. 4), preceding by about half an hour a local magnitude 3.5 earthquake in December 2002, which involved the shallow part of the Psathopyrgos Fault, at about $2 \mathrm{~km}$ in 


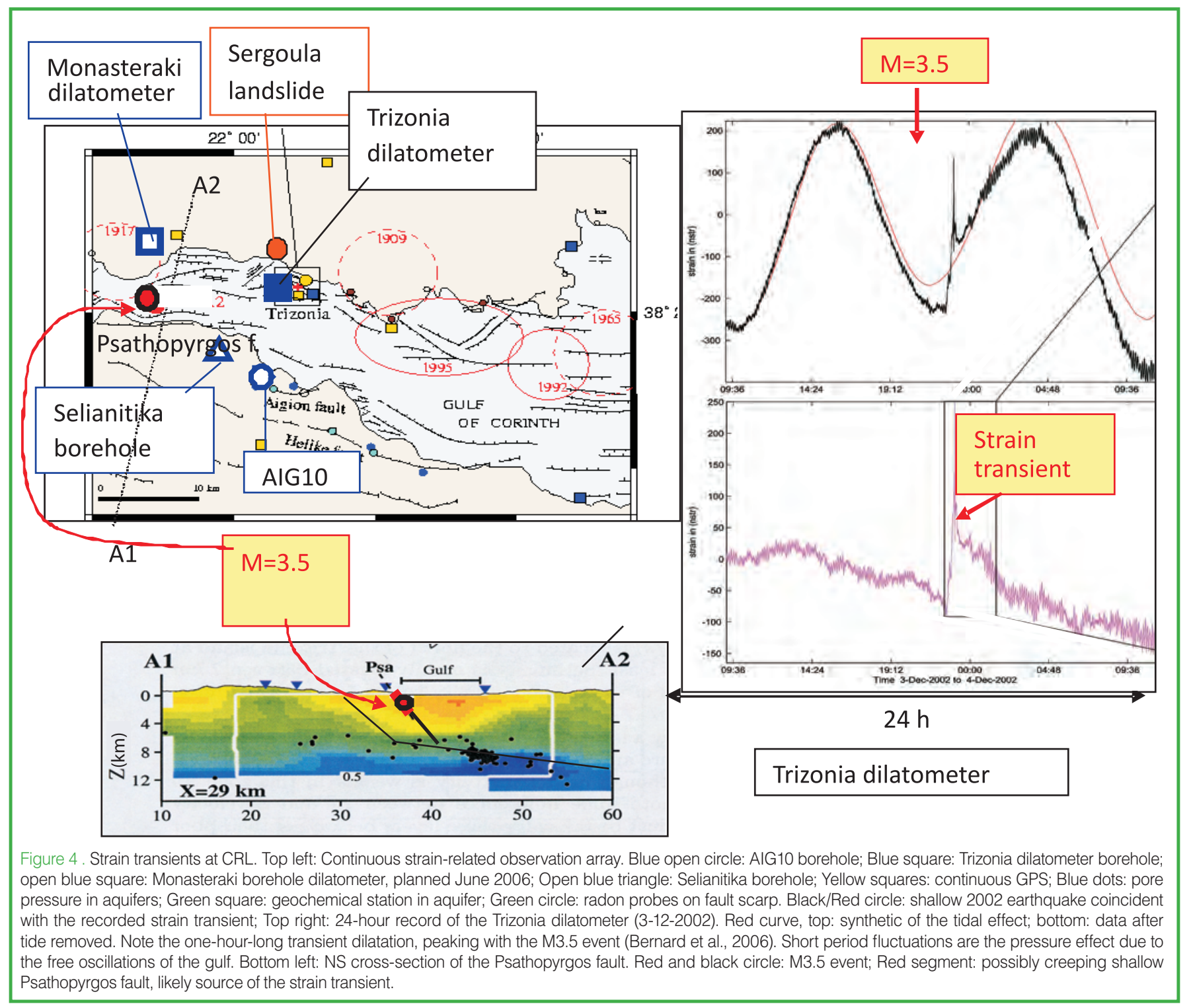

depth (equivalent magnitude 5), i.e., well above the seismogenic zone of the area (Bernard et al., 2006). This earthquake was also the largest of a seismic swarm located about $15 \mathrm{~km}$ west of the CRL seismic network that lasted six weeks and involved deeper parts of the same fault.

The present plan is to deploy a complete suite of packers, high frequency $(2.5 \mathrm{KHz}$ sampling rate) 3C geophones, hydrophones $(2.5 \mathrm{KHz}$ sampling rate), high precision pressure transducers, thermistors, and tilt meters on both sides of the Aigion fault (February 2007). These data will be part of a feasibility study for drilling down to $5 \mathrm{~km}$ for sampling circulating fluids and monitoring high frequency signals within the seismogenic zone.

\section{Acknowledgements}

CRL was developed from 1999 to 2003 mostly through European funding and with the support of the International Continental Drilling Program for the drilling of AIG10. It has benefited greatly also from continuous support from the
French National Centre for Scientific Research (CNRS) since 1999.

\section{References}

Armijo, R., Meyer, B., King, G.C.P., Rigo, A., and Papanastassiou, D., 1996. Quaternary evolution of the Corinth Rift and its implications for the late Cenozoic evolution of the Aegean. Geophys. J. Int., 126:11-53.

Avallone, A., Briole, P., Agatza-Balodimou, A.M., Billiris, H., Charade, O., Mitsakaki, C., Nercessian, A., Papazissi, K., Paradissis, D., and Veis, G., 2004. Analysis of eleven years of deformation measured by GPS in the Corinth Rift Laboratory area. C. R. Geoscience, 336(4-5):301-312.

Bernard, P., Briole, P., Meyer, B., Lyon-Caen, H., Gomez, J.M., Tiberi, C., Berge, C., Cattin, R., Hatzfeld, D., et al., 1997. The $\mathrm{Ms}=6.2$, June 15, 1995 Aigion earthquake (Greece): evidence for low angle normal faulting in the Corinth rift. Journal of Seismology, 1:131-150.

Bernard, P., Lyon-Caen, H., Briole, P., Deschamps, A., Boudin, F., Macropoulos, K., Papadimitriou, P., Lemeille, F., Patau, G., 
Billiris, H., Paradissis, D., Papazissi, K., Castarède, H., Charade, O., Nercessian, A., Avallone, A., Pacchian, F., Zaradnick, J., Sacks, S., and Linde, A., 2006. Seismicity, deformation and seismic hazard in the western rift of Corinth: new insights from the Corinth rift laboratory (CRL). Tectonophysics, 426:7-30.

Bourouis, S., Bouin, M.P., Patau, G., Bernard, P., Lyon-Caen, H., and Deschamps, A., 2005. The Corinth Riftlaboratory-Multiplet analysis of the January 2004 microseismic crisis. European Geosciences Union Annual Meeting, Vienna.

Briole, P., Rigo, A., Lyon-Caen, H., Ruegg, J.C., Papazissi, K., Mitsakaki, C., Balodimou, A., Veis, G., Hatzfeldand, D., and Deschamps, A., 2000. Active deformation of the Corinth Rift, Greece : results from repeated Global Posiontioning Systems surveys between 1990 and 1995. J. Geophys. Res., 105:25605-25625.

Comptes Rendus Geoscience, 2004. 336(4/5); (special issue on Corinth Rift, with 25 papers).

Cornet, F.H., Bourouis, S., and the CRL Team, 2005. Estimate of hydraulic diffusivity at $8 \mathrm{~km}$ depth in the Corinth Rift (Greece) from seismic activity migration. AGU Fall Meeting, San Francisco.

Cornet, F.H., Borm, G., McEvilly, T., and Vardoulakis, I., (Orgs.), 1997. Development of a multi-borehole observatory at the Gulf of Corinth, Athens. In Proceedings of the 1st workshop on the development of a multiborehole observatory at the Gulf of Corinth. 26-28 October 1997, Athens. 1997 ICDP 1996-1997 report available at http://www.corinth-rift-lab. org.

Cornet, F.H., Doan, M.L., Moretti, I., and Borm, G., 2004. Drilling through the active Aigion Fault: The AIG10 well observatory. C. R. Geoscience, 336:395-406.

Doan, M.L. and Cornet, F.H., 2007. Small pressure drop triggered near a fault by small teleseismic waves. Earth Planet. Sci. Lett., in press.

Gautier, S., Latorre, D., Virieux, J., Deschamps, A., Skarpelos, S., Sotiriou, A., Serpetsidaki, A., and Tselentis, A., 2006. A new passive tomography of the Aigion Area (Gulf of Corinth, Greece) from the 2002 data set. Pageoph., 163(2-3);431-453, doi:10.1007/s00024-005-0033-7.

Jolivet, L., Famin, V., Mehl, C., Parra, T., Avigad D., and Aubourg, C., 2004. Progressive strain localisation, crustal scale boudinage and extensional metamorphic domes in the Aegean sea. American Geological Society, Special paper 380, 185-210.

Le Pichon, X., Chamot-Rooke, N., Lallement, S., Noomen, R., and Veis, G., 1995. Geodetic determination of the kinematics of central Greece with respect to Europe: implications for Eastern Mediterranean tectonics. J. Geophys. Res., 100(B7):12675-12690.

Lyon-Caen, H., Papadimitriou, P., Deschamps, A., Bernard, P., Makropoulos, K., Pacchiani, F., and Patau, G., 2004. First results of the CRL seismic network in the western Corinth Rift: evidence for old fault reactivation. C. R. Geoscience, 336:343-352.

Pantosti, D., De Martini, P.M., Koukouvelas, I., Stamatopoulos, L., Palyvos, N., Pucci, S., Lemeille, F., and Pavlides, S., 2004.
Palaeoseismological investigations of the Aigion Fault (Gulf of Corinth, Greece). C. R. Geoscience, 336:335-342.

Rigo, A., Lyon-Caen, H., Armijo, R., Deschamps, A., Hatzfeld, D., Makropoulos, K., Papadimitriou, P., Kassaras, P., and Kassaras, L., 1996. A microseismic study of the western part of the Gulf of Corinth (Greece): implications for the large-scale normal faulting mechanisms. Geophys. J. Int., 126:663-688.

Sulem, J., 2007. Stress orientation evaluated from strain localisation analysis in Aigion fault. Tectonophysics, 442(1):3-13.

\section{Related Web Link}

http://www.corinth-rift-lab.org

\section{Author}

François Henri Cornet, Institut de Physique du Globe de Strasbourg, 5 rue René Descartes, 67000 Strasbourg, France, e-mail: francois.cornet@eost.u-strasbg.fr. 